\title{
Colony cycle of the social wasp Mischocyttarus consimilis Zikán (Hymenoptera, Vespidae)
}

\author{
Viviana O. Torres ${ }^{1}$, Thiago S. Montagna ${ }^{1}$, Wedson D. Fernandes ${ }^{2} \&$ William F. Antonialli-Junior ${ }^{1}$
}

\begin{abstract}
${ }^{1}$ Centro Integrado de Análise e Monitoramento Ambiental, Universidade Estadual de Mato Grosso do Sul, 79804-970 Dourados-MS, Brazil. vivianabio@yahoo.com.br; thiagomontag@yahoo.com.br; williamantonialli@yahoo.com.br

${ }^{2}$ Faculdade de Ciências Biológicas e Ambientais, Universidade Federal da Grande Dourados, 79804-970 Dourados-MS, Brazil. wedsonfernandes@ufgd.edu.br
\end{abstract}

\begin{abstract}
Colony cycle of the social wasp Mischocyttarus consimilis Zikán (Hymenoptera, Vespidae). This study describes some aspects of the colony cycle of the Neotropical social wasp Mischocyttarus consimilis, from data obtained under field conditions. Our results showed that the colony cycle in M. consimilis is annual and asynchronous in relation to the months of the year. The colonies remained active for approximately eight months. Most of the abandonments were associated with natural causes, and were most frequent in the pre-emergence stage. The nests were constructed preferentially in man-made structures, especially in sites protected from direct sunlight and rain. Colony foundation was either by haplometrosis or pleometrosis, being the first form predominant.
\end{abstract}

KEYWORDS. Colony development; natural history; neotropical wasp; phenology; Polistinae.

RESUMO. Ciclo colonial da vespa social Mischocyttarus consimilis Zikán (Hymenoptera, Vespidae). Este estudo descreve alguns aspectos do ciclo colonial da vespa social Neotropical Mischocyttarus consimilis, sendo realizado em condições de campo. Os resultados desse estudo mostraram que o ciclo colonial em M. consimilis é anual, bem como assincrônico em relação aos meses do ano. Em geral, as colônias permanecem em atividade por aproximadamente oito meses. Os abandonos de colônia estão associados principalmente a causas naturais, e são mais freqüentes na fase colonial de pré-emergência. Os ninhos são estabelecidos preferencialmente em construções humanas, especialmente em locais protegidos da incidência direta de luz solar e água da chuva. Fundações de colônia ocorrem por uma ou outra forma haplometrose ou pleometrose, sendo a primeira predominante.

PALAVRAS-CHAVE. Desenvolvimento colonial; fenologia; história natural; Polistinae; vespa neotropical.

In polistine wasps, the periodicity of the foundation and abandonment of colonies differs between species of tropical and temperate climates (Gadagkar 1991; Reeve 1991). In temperate areas, the colony cycle is synchronized with the seasons, beginning in the middle of spring and finishing at the end of autumn or beginning of winter (West-Eberhard 1969). In these conditions there is a period of inactivity that extends from the abandonment of the colonies to the new foundations, during which the wasps hibernate (Yoshikawa 1963). This period is characterized by the formation of aggregations, which are initially constituted by males and later by potentially reproductive females, which after they abandon the maternal nest, migrate to sheltered locations or old abandoned nests (Spradbery 1973). In general, the mating of the potentially reproductive females occurs in their own aggregation, and during the winter (Yoshikawa 1963; Spradbery 1973).

In contrast, the colony cycle of social wasps in tropical areas is relatively longer, occasionally more than a year (Giannotti 1997). In these conditions, colonies are founded and abandoned at any time of year (Gobbi \& Zucchi 1980). Thus, colonies in different stages of development can occur in the same population in the same period, and this nesting cycle pattern is termed asynchronous (Wilson 1971). How- ever, under adverse climate conditions (e.g., low temperatures in winter), the colony cycle of tropical wasps can be occasionally interrupted, and show characteristics similar to the cycle of temperate wasps (González et al. 2002; TannureNascimento et al. 2005; Gobbi et al. 2006).

In polistine wasps, the colonies are founded either independently or swarms form (Jeanne 1980). In independent foundations, one or more foundresses unaccompanied by workers begin a new colony, which can occur either haplometrotic or pleometrotic forms (Gadagkar 1991). Independent-foundation species generally contains few individuals in the colony, and the nests do not possess a covering envelope (Gadagkar 1991). This foundation pattern can be found in four genera of Polistinae (Polistes, Mischocyttarus, Belonogaster, and Parapolybia) and in some species of Ropalidia (Gadagkar 1991). The objective of this study was to describe in detail the colony cycle of the social wasp Mischocyttarus consimilis Zikán, 1949.

\section{MATERIAL AND METHODS}

Study site and climate characterization. The study was conducted under field conditions in an area of approximately two hectares on the campus of the Universidade Federal da 
Grande Dourados, in the municipal district of Dourados (22 $2^{\circ} 13^{\prime} 16^{\prime \prime}$; ; 54 $48^{\prime} 20^{\prime \prime} \mathrm{W}$ ), state of Mato Grosso do Sul in central-western Brazil. The study area is characterized by intense movement of people and sparse vegetation among the buildings. The climate of this region, according to Zavatini (1992), is humid subtropical, with higher precipitation and temperatures in September through February (Warm-Rainy Season), and less precipitation and mild temperatures in March through August (Cold-Dry Season). The climate data were obtained from the Embrapa meteorological station in the Dourados district.

Colonial phenology. The colonial phenology was studied for one year, during which a total of 94 colonies were observed. The foundations and abandonments of colonies were determined through weekly censuses in the study area, from September 2007 through August 2008. Most of the colonies were observed from their foundation until they were abandoned. We collected data on established colonies three times a week on designated days.

We considered "foundation" to be the period from the construction of the petiole until the first egg was laid, "activity" the period from the first egg laid until the declining colony stage, and "abandonment" when the last wasp left the nest. The reasons for the abandonment of a colony were assessed, and were assigned to "natural causes" if the nest was complete in the nesting site, "human action" if the nest was totally removed from the nesting site and "predation" if the nest was partly destroyed or if ants were occupying it. The term "natural causes" was only used for nests that were abandoned for no apparent reason and that were monitored rigorously.

Duration of the colony stage. The duration of the colony stage and the densities of adults and immatures were determined by daily monitoring of each colony, from June 2007 through July 2008. The colony stage and sub-stage were defined according to Jeanne (1972), as "pre-emergence stage" from the foundation of the nest to the emergence of the first imago; "egg sub-stage" from the first egg laid to the appearance of the first larva; "larval sub-stage" from the appearance of the first larva to the formation of the first pupa; "pupal sub-stage" from the formation of the first pupa to the emergence of the first imago; "post-emergence stage" from the emergence of the first imago to the beginning of the colony decline and "declining stage" from the beginning of irreversible reduction of the numbers of immatures to the total abandonment of the nest.

Foundation patterns. The foundation pattern and the colony success were observed for 59 colonies. We determined the pattern of colony foundation considering the "substrate" used to attach the nest and the "number of females" that participated in the foundation stage of the colony. We considered that the colony was a success when it reached at least the postemergence stage, i.e., produced at least one adult individual.

Statistical analysis. Correlation analysis was used to evaluate if climate variables (air temperature and relative humidity) influenced the numbers of foundations and aban- donments. The variable was considered significant when the $p$-values were less than 0.05 . The software utilized was SYSTAT $12^{\circledR}$.

\section{RESULTS AND DISCUSSION}

Colonial phenology. Richards (1978) mentioned that $M$. consimilis was restricted to Paraguay, and therefore the present report constitutes the first record for the species in Brazil. Our data showed that colonies of $M$. consimilis are founded throughout the year. The highest and lowest foundation frequencies were, respectively, in August (16\%), the beginning of the rainy season; and in May (2\%), the middle of the dry season (Fig. 1). Similarly, abandonments were common during the entire year, being most frequent in November $(14 \%)$, moderate in the rainy season, and least frequent in June (2\%), in the middle of the dry season (Fig. 1 ). The nesting cycle was asynchronous in respect to the months of the year, and colonies in different stages occurred simultaneously in the population at any time of the year. This regular siting of new colonies by $M$. consimilis is a common condition in wasps of tropical regions, because in these conditions the clime does not restrict the activity of the colonies (Jeanne 1972; Gobbi \& Zucchi 1980). Another factor that favors nesting cycle asynchrony in tropical wasps is the constant presence of males in the population, which allows the fertilization of reproductive females during the entire year (Hunt 1999). Data from other studies with conspecific tropical wasps, for instance M. drewseni (de Saussure, 1854) (Jeanne 1972; Penna et al. 2007), M. mastigophorus Richards, 1978 (O’Donnell \& Joyce 2001), M. cassununga (von Ihering, 1903) (Poltronieri \& Rodrigues 1976), and M. cerberus styx Richards, 1940 (Giannotti 1998) are congruent with the colony asynchrony shown by $M$. consimilis.

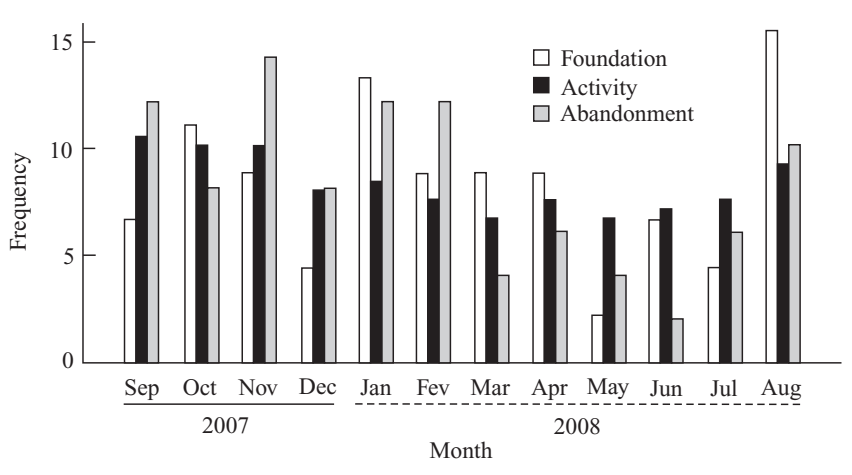

Fig. 1. Frequency of foundation, activity, and abandonments for 94 colonies of Mischocyttarus consimilis, from September 2007 through August 2008.

Our results also showed that temperature significantly influenced the number of abandonments $(\mathrm{r}=0.86 ; p<0.01$; $\mathrm{n}=12)$. However, temperature did not influence the number of foundations $(\mathrm{r}=0.62 ; p=0.19 ; \mathrm{n}=12)$. The relative humidity did not significantly influence either the number of 
foundations $(\mathrm{r}=0.42 ; p=0.56 ; \mathrm{n}=12)$ or the number of abandonments $(\mathrm{r}=0.67 ; p=0.13 ; \mathrm{n}=12)$. These data suggest that constancy of foundation and abandonment of colonies is associated with slight climate variation during the year, leading to the nesting cycle asynchrony. WestEberhard (1969), studying wasps of temperate regions, observed that the abandonments in those regions were motivated mainly by the negative variation of temperature. Our data suggest that abandonments in warmer periods may be exceptional for tropical species. In any event, these data taken together strongly support the effect of temperature variation as the main environmental factor associated with colony abandonment in social wasps, in both temperate and tropical regions.

The main reasons for the abandonments were natural causes $(63 \%)$, human action $(21 \%)$, and predation $(16 \%)$ (Table I). The abandonments showed a frequency of $51 \%$ in the pre-emergence, $33 \%$ in the post-emergence, and $16 \%$ in the declining stage (Table I). Abandonments because of predation were uncommon, but were more frequent in pre-emerging or declining colonies, and occurred when these contained, soon before they were abandoned, a mean of 19.7 \pm 15.1 cells and $1.5 \pm 1.0$ adults (Table I). In the abandonments from natural causes, the colonies contained a mean of $37.2 \pm 48.2$ cells and $1.6 \pm 1.1$ adults (Table I). Considering the colony stage, the abandoned colonies contained on average $13.1 \pm 10.1$ cells and $1.3 \pm 0.8$ adults in the pre-emergence, $29.9 \pm 18.2$ cells and $1.6 \pm 0.6$ adults in the post-emergence, and $110.1 \pm 48.6$ cells and $3.2 \pm 1.4$ adults in the declining stage (Table I). The abandonments motivated by predation occurred mainly because of attacks by ants. According to Jeanne (1975) and Downing (1991), ants are the main predators of social wasps that build petioled nests without an envelope.

Duration of the colony stage and density of broods and adults. The complete colony cycle of $M$. consimilis had a mean duration of 234.9 days (Table II); however, some exceptional colonies remained active for more than one year (personal observation). This duration is similar to the eight months reported by Litte (1977) for M. mexicanus (de Saussure, 1854) and by Litte (1979) for M. flavitarsis (de
Saussure, 1854), both species of temperate areas, and longer than the 160 days reported by Jeanne (1972) for M. drewseni as well as the 181 days reported by Gobbi and Simões (1988) for M. cassununga, both tropical species.

The mean duration of the pre-emergence stage in $M$. consimilis was 66.6 days. The egg, larval, and pupal sub-stages had mean durations of $14.0 \pm 5.2,31.7 \pm 10.4$, and $22.1 \pm 5.3$ days respectively (Table II). The duration of the pre-emergence stage was shorter than the 73.5 days described by Giannotti (1998) for M. cerberus styx. In detail, we observed that the pre-emergence stage in pleometrotic foundations was longer than the haplometrotic. In pleometrosis the foundation phase was marked by antagonistic behaviors among the foundresses until the establishment dominance. Our results showed that in the pre-emergence stage, each colony contained $2.1 \pm 1.6$ adults, and the immature were composed of $51 \%$ eggs, $36 \%$ larvae, and $13 \%$ pupae, occupying $91 \%$ of the comb (Table III). In this stage, the nests contained 20.6 cells on average (Table III).

The post-emergence stage comprised most of the colonial cycle, lasting on average $148.6 \pm 70.5$ days (Table II). In this stage, the colonies had a mean of $6.4 \pm 4.5$ adults, and the immatures comprised 36\% eggs, 50\% larvae, and 14\% pupae, occupying $93 \%$ of the comb (Table III). In this stage, the nests contained a mean of 65.1 cells (Table III). The duration of the post-emergence stage in $M$. consimilis was less than the 182.8 days reported by Giannotti (1998) for $M$. cerberus styx. The post-emergence stage in $M$. consimilis was

Table II. Duration of the colony developmental stages and sub-stages in Mischocyttarus consimilis (Mean $\pm \mathrm{SD}$ ).

\begin{tabular}{cccccc}
\hline & \multicolumn{5}{c}{ Pre-emergence } \\
\cline { 2 - 5 } & Egg & Larva & Pupa & & \\
\hline & $14.0 \pm 5.2$ & $31.7 \pm 10.4$ & $22.1 \pm 5.3$ & $148.6 \pm 70.5$ & $18.5 \pm 9.8$ \\
Duration & $(9-22)$ & $(14-46)$ & $(14-28)$ & $(72-211)$ & $(8-30)$ \\
(Days) & $\mathrm{n}=7$ & $\mathrm{n}=7$ & $\mathrm{n}=7$ & $\mathrm{n}=3$ & $\mathrm{n}=4$ \\
\cline { 2 - 4 } & 66.6 & & \\
\cline { 2 - 4 } & \multicolumn{5}{c}{234.9} \\
\hline
\end{tabular}

Table I. Frequency of abandonments during the different colony stages and the main causes, and the number of cells and adults present in the nest soon before colonies of Mischocyttarus consimilis were abandoned (Mean $\pm \mathrm{SD}$ ).

\begin{tabular}{|c|c|c|c|c|c|c|}
\hline & \multicolumn{3}{|c|}{ Causes } & \multicolumn{3}{|c|}{ Stage } \\
\hline & Predation & Human action & Natural causes & Pre-emergence & Post-emergence & Declining \\
\hline Frequency (\%) & 16 & 21 & 63 & 51 & 33 & 16 \\
\hline \multirow[t]{3}{*}{ Numbers of cells } & $19.7 \pm 15.1$ & $41.7 \pm 35.2$ & $37.2 \pm 48.2$ & $13.1 \pm 10.1$ & $29.9 \pm 18.2$ & $110.1 \pm 48.6$ \\
\hline & $(7-52)$ & $(8-100)$ & $(4-215)$ & $(4-44)$ & $(8-70)$ & $(52-215)$ \\
\hline & $\mathrm{n}=9$ & $\mathrm{n}=8$ & $\mathrm{n}=30$ & $\mathrm{n}=25$ & $\mathrm{n}=14$ & $\mathrm{n}=8$ \\
\hline \multirow[t]{3}{*}{ Numbers of adults } & $1.5 \pm 1.0$ & $2.5 \pm 0.9$ & $1.6 \pm 1.1$ & $1.3 \pm 0.8$ & $1.6 \pm 0.6$ & $3.2 \pm 1.4$ \\
\hline & $(1-4)$ & $(1-4)$ & $(1-5)$ & $(1-4)$ & $(1-3)$ & $(1-5)$ \\
\hline & $\mathrm{n}=9$ & $\mathrm{n}=8$ & $\mathrm{n}=30$ & $\mathrm{n}=25$ & $\mathrm{n}=14$ & $\mathrm{n}=8$ \\
\hline
\end{tabular}


Table III. Frequency of occupation of cells by immatures, and number of adults in the different colony stages in colonies of Mischocyttarus consimilis (Mean \pm SD).

\begin{tabular}{|c|c|c|c|c|c|c|c|}
\hline & & \multicolumn{3}{|c|}{ Immature } & \multicolumn{2}{|c|}{ Cell } & \multirow{2}{*}{ Adult } \\
\hline & & Egg & Larva & Pupa & Occupied & Empty & \\
\hline \multirow[t]{4}{*}{ Pre-emergence stage } & Frequency $(\%)$ & 51 & 36 & 13 & 91 & 9 & - \\
\hline & Number & $9.6 \pm 8.9$ & $6.7 \pm 4.6$ & $2.3 \pm 2.4$ & $18.7 \pm 13.5$ & $1.9 \pm 2.2$ & $2.7 \pm 1.6$ \\
\hline & & $(1-29)$ & $(1-18)$ & $(1-8)$ & $(5-47)$ & $(0-6)$ & $(1-7)$ \\
\hline & & $\mathrm{n}=11$ & $\mathrm{n}=11$ & $\mathrm{n}=11$ & $\mathrm{n}=11$ & $\mathrm{n}=11$ & $\mathrm{n}=11$ \\
\hline \multirow[t]{4}{*}{ Post-emergence stage } & Frequency $(\%)$ & 36 & 50 & 14 & 93 & 7 & - \\
\hline & Number & $22.0 \pm 9.0$ & $31.2 \pm 22.1$ & $8.5 \pm 5.7$ & $60.6 \pm 28.8$ & $4.4 \pm 4.7$ & $6.4 \pm 4.5$ \\
\hline & & $(7-35)$ & $(12-85)$ & $(3-17)$ & $(23-123)$ & $(0-11)$ & $(2-16)$ \\
\hline & & $\mathrm{n}=9$ & $\mathrm{n}=9$ & $\mathrm{n}=9$ & $\mathrm{n}=9$ & $\mathrm{n}=9$ & $\mathrm{n}=9$ \\
\hline \multirow[t]{4}{*}{ Declining stage } & Frequency $(\%)$ & 34 & 49 & 17 & 50 & 50 & - \\
\hline & Number & $12.5 \pm 5.1$ & $17.7 \pm 13.8$ & $6.2 \pm 9.1$ & $37.2 \pm 27.4$ & $37.0 \pm 28.4$ & $5.0 \pm 5.6$ \\
\hline & & $(5-16)$ & $(8-38)$ & $(1-20)$ & $(15-77)$ & $(19-79)$ & $(1-13)$ \\
\hline & & $\mathrm{n}=4$ & $\mathrm{n}=4$ & $\mathrm{n}=4$ & $\mathrm{n}=4$ & $\mathrm{n}=4$ & $\mathrm{n}=4$ \\
\hline
\end{tabular}

marked by accentuated growth of the colony, adding cells as well as producing adults. The first individuals produced were always females, precisely workers that were destined for the maintenance and defense of the colony. The few males seen in this study generally emerged at the end of the post-emergence stage, when the colonies contained a high density of adults. In this stage, the few cells that did not contain immatures were located on the periphery of the comb and were used mainly for nectar storage.

The declining stage had a mean duration of $18.5 \pm 9.8$ days (Table II). The duration of this stage was less than the 23.1 days reported by Giannotti (1998) for M. cerberus styx. In this stage, the colonies contained $5.0 \pm 5.6$ adults, and the immatures consisted of 34\% eggs, $49 \%$ larvae, and $17 \%$ pupae, occupying $50 \%$ of the comb (Table III). In addition, the cells that did not contain immatures generally remained empty. In this stage, the nests contained a mean of 74.2 cells (Table III). As shown by West-Eberhard (1969) for Polistes, the declining stage was characterized by the addition of few or no cells to the comb, and an irreversible reduction in the numbers of adults and immatures in the colony, as well as progressive dysfunction of the social organization of the colony before the abandonment of the nest.

Foundation patterns and colony success. The data this study showed that the foundation of colonies in $M$. consimilis can be either haplometrotic or pleometrotic form, although haplometrosis predominated throughout the year. In pleometrosis, the number of foundresses ranged from two $(17 \%)$ to six $(2 \%)$, these being the most and least frequent numbers respectively (Fig. 2A). Foundations with five females were unrecorded. The success of the colonies initiated by a single female was $44 \%$, and that of colonies initiated by more than two females was always above 50\% (Fig. 2A). The success rate for colonies founded by four or six females was $100 \%$ (Fig. 2A). The predominance of haplometrotic foundation shown for $M$. consimilis was different from that described by Itô (1984) for M. angulatus Richards, 1945 and M. basimacula (Cameron, 1906). In the pleometrotic foundations, the association of females occurred in most cases after a female had begun the nest. In colonies in which the association occurred after the foundation, the queen was as a rule the founders that began the nest. The queen in the pleometrotic foundation was established mainly by differential oophagies.

There was no relationship between the pattern of colony foundation and the success of the colony; contradictorily, haplometrotic foundation was the more common and the less successful. It could be hypothesized that because of the need for physical combat for establishment of dominance in pleometrotic foundations, the haplometrotic foundation appears to be selected. The haplometrotic foundation could be preferred initially to preserve the physical integrity of the foundress, and to increase the chance of success of the colony. However, the haplometrotic foundation is more susceptible to the attack of predators (Gamboa 1978; Gamboa et al. 1992; Ito \& Itioka 2008). Thus, the haplometrotic foundation would be selected only if the predation rate is low in a population (Gamboa et al. 1992; Liebert et al. 2005; Tibbetts \& Reeve 2003). Therefore, it is suggested that the decision for either haplo- or pleometrosis foundation is closely associated with the surrounding predation rate. Although it needs to be further explored, this hypothesis seems to be valid for M. consimilis, because during the study period there were a concomitant low predation rate and a preference for solitary foundation.

All of the colonies observed were found on human-made structures, especially in locations protected from direct sunlight and rain. Overall, $46 \%$ of the nests were located on metal structures, $49 \%$ on concrete, and $5 \%$ on asbestos tiles (Fig. 2B). The success rate was $67 \%$ on asbestos tiles, $66 \%$ on concrete, and $59 \%$ on metal structures (Fig. 2B). Although 
asbestos tiles were equally abundant in the study location, there was a certain preference for foundation on metal structures and concrete. The low number of foundations on asbestos tiles can be explained partly by the exposure of most of the tiles to the sun, which, depending on the degree of shade, provided unfavorable physical conditions for the maintenance of colonies; all the successful colonies established on tiles were partly protected from direct sunlight. This suggests that the places selected for nesting are necessarily those that provide better climate conditions.
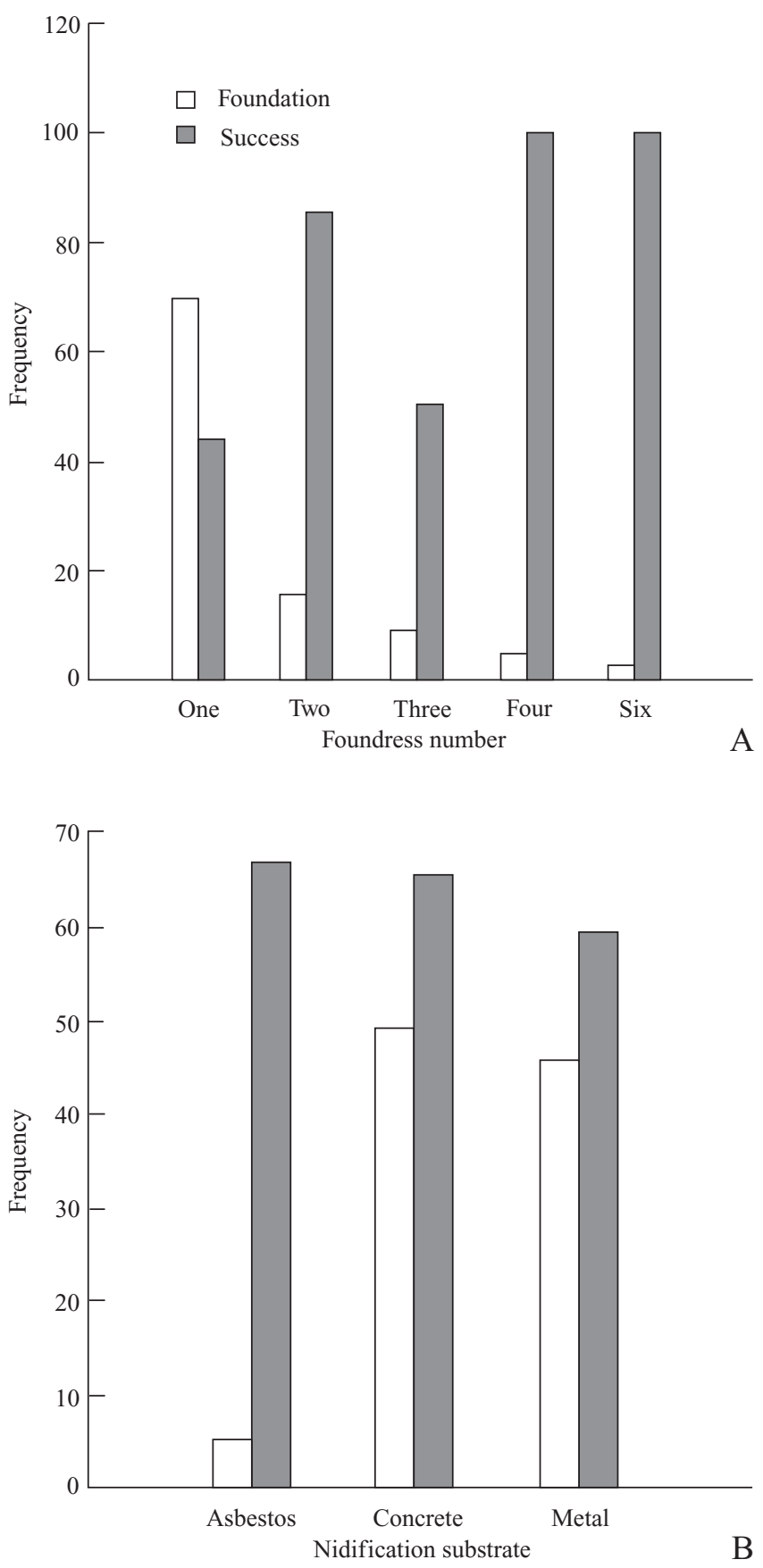

Fig. 2. Frequency of foundations and colony success: (A) number of females present in the foundation phase, and (B) nidification substrate.

\section{ACKNOWLEDGMENTS}

The authors thank Janet W. Reid (JWR Associates) for the revision of the English text, Orlando T. Silveira (Museu Paraense Emílio Goeldi) for the identification of the species studied, $\mathrm{CNPq}$ for financial support to the second author (CNPq Process 132211/2008-4) and WFAJ acknowledges his research grants from $\mathrm{CNPq}$.

\section{REFERENCES}

Downing, H. A. 1991. The function and evolution of exocrine glands, p. 540-569. In: K. G. Ross \& R. W. Matthews (eds.). The social biology of wasps. Ithaca, Cornell University Press, xvii+678 p.

Gadagkar, R. 1991. Belonogaster, Mischocyttarus, Parapolybia, and independent founding Ropalidia, p. 149-190. In: K. G. Ross \& R. W. Matthews (eds.). The social biology of wasps. Ithaca, Cornell University Press, xvii+678 p.

Gamboa, G. J. 1978. Intraspecific defense: Advantage of social cooperation among paper wasp foundresses. Science 199: 1463-1465.

Gamboa, G. J.; T. L. Wacker; K. G. Duffy; S. W. Dobson \& T. G. Fishwild. 1992. Defence against intraspecific usurpation by paper wasp cofoundresses (Polistes fuscutus, Hymenoptera: Vespidae). Canadian Journal of Zoology 70: 2369-2372.

Giannotti, E. 1997. Biology of the wasp Polistes (epicnemius) cinerascens Saussure (Hymenoptera: Vespidae). Anais da Sociedade Entomológica do Brasil 26: 61-67.

Giannotti, E. 1998. The colony cycle of the social wasp, Mischocyttarus cerberus styx Richards, 1940 (Hymenoptera, Vespidae). Revista Brasileira de Entomologia 41: 217-224.

Gobbi, N. \& R. A. Zucchi. 1980. On the ecology of Polistes versicolor (Olivier) in southern Brazil (Hymenoptera, Vespidae, Polistini). I: Phenological account. Naturalia 5: 97-104.

Gobbi, N \& D. Simões. 1988. Contribuição ao entendimento do ciclo básico de colônias de Mischocyttarus (Monocyttarus) cassununga von Ihering, 1903 (Hymenoptera, Vespidae). Anais da Sociedade Entomológica do Brasil 17: 421-436.

Gobbi, N.; F. B. Noll \& M. A. H. Penna. 2006. "Winter" aggregations, colony cycle, and seasonal phenotypic change in the paper wasp Polistes versicolor in subtropical Brazil. Naturwissenschaften 93: 487-494.

González, J. A.; F. S. Nascimento \& S. F. Gayubo. 2002. Observations on the winter aggregates of two polistine paper wasps (Hymenoptera Vespidae Polistinae). Tropical Zoology 15: 1-4.

Hunt, J. H. 1999. Trait mapping and salience in the evolution of eusocial vespid wasps. Evolution 53: 225-237.

Itô, Y. 1984. Social behaviour and social structure of Neotropical paper wasps Mischocyttarus angulatus (Richards) and M. basimacula (Cameron). Journal of Ethology 2: 17-29.

Itô, Y. \& T. Itioka. 2008. Demography of the Okinawan eusocial wasp Ropalidia fasciata (Hymenoptera: Vespidae) II. Effects of foundress group size on survival rates of colonies and foundresses, and production of progeny. Entomological Science 11: 17-30.

Jeanne, R. L. 1972. Social biology of the Neotropical wasp Mischocyttarus drewseni. Bulletin of the Museum of Comparative Zoology 144: 63150.

Jeanne, R. L. 1975. The adaptiveness of social wasp nest architecture. The Quarterly Review of Biology 50: 267-287.

Jeanne, R. L. 1980. Evolution of social behavior in the Vespidae. Annual Review of Entomology 25: 371-396.

Liebert, A. E.; P. Nonacs \& R. K. Wayne. 2005. Solitary nesting and reproductive success in the paper wasp Polistes aurifer. Behavioral Ecology and Sociobiology 57: 445-456.

Litte, M. 1977. Behavioral ecology of the social wasp Mischocyttarus mexicanus. Behavioral Ecology and Sociobiology 2: 229-246. 
Litte, M. 1979. Mischocyttarus flavitarsis in Arizona: Social and nesting biology of a polistine wasp. Zeitschrift für Tierpsychologie 50: 282 312.

O’ Donnell, S. \& F. J. Joyce. 2001. Seasonality and colony composition in a montane tropical eusocial wasp. Biotropica 33: 727-732.

Penna, M. A. H.; N. Gobbi \& H. C. Giacomini. 2007. An evaluation of the productivity of Mischocyttarus drewseni in a semi-urban environment (Hymenoptera: Polistinae). Sociobiology 50: 113-120.

Poltronieri, H. S. \& V. M. Rodrigues. 1976. Vespídeos sociais: estudos de algumas espécies de Mischocyttarus Saussure, 1853 (Hymenoptera.Vespidae. Polistinae). Dusenia 9: 99-105.

Reeve, H. K. 1991. Polistes, p. 99-148. In: K. G. Ross \& R. W. Matthews (eds.). The social biology of wasps. Ithaca, Cornell University Press, xvii+678 p.

Richards, O. W. 1978. The social wasps of the Americas excluding the Vespinae. London, British Museum (Natural History), vii+580 p.

Spradbery, J. P. 1973. Wasps: an account of the biology and natural history of solitary and social wasps. Seattle, University of Washington Press, $\mathrm{xvi}+408 \mathrm{p}$.

Tannure-Nascimento, I. C.; F. S. Nascimento \& R. Zucchi. 2005. Size and colony cycle in Polistes satan, a Neotropical paper wasp (Hymenoptera Vespidae). Ethology Ecology and Evolution 17: 105-119.

Tibbetts, E. A. \& H. K. Reeve. 2003. Benefits of foundress associations in the paper wasp Polistes dominulus: increased productivity and survival, but no assurance of fitness returns. Behavioral Ecology 14: 510-514.

West-Eberhard, M. J. 1969. The social biology of polistine wasps. Miscellaneous Publications, Museum of Zoology, University of Michigan 140: 1-101.

Wilson, E. O. 1971. The insect societies. Cambridge, Belknap Press, $x+548$ p. Yoshikawa, K. 1963. Introductory studies on the life economy of polistine wasps. V. Three stages relating to hibernation. Journal of Biology, Osaka City University 14: 87-96.

Zavatini, J. A. 1992. Dinâmica climática no Mato Grosso do Sul. Geografia 17: $65-91$.

Received 28/4/2010; accepted 19/4/2011

Editor: Maria Cristina Gaglianone 